\title{
VOLITIONAL STRATEGIES THROUGH METACOGNITIVE DEVELOPMENT IN FOSTERING READING MOTIUATION
}

\author{
Vismaia S. Damaianti \\ Universitas Pendidikan Indonesia \\ vismaia@upi.edu
}

First received: 6 April 2017

Final proof received: 28 September 2017

\begin{abstract}
Student's reading skill is deemed vitally important to attain high academic achievements. The results of the previous studies, however, show that Indonesian students' reading skill is still unsatisfying due to their low motivation. The purpose of this study is to address this problem of students' motivation by examining the effectiveness of a volitional strategy through metacognitive development to students of Islamic Junior High School [Madrasah Tsanawiyah] in Indonesia. A quasi-experimental method with a factorial design is used in this research. Indicators for increasing students' reading motivation come from Cambria and Guthrie (2010). Measures of increased motivation to read with the volitional strategy were done through metacognitive development which is based on self-monitoring and awareness of reading skills mastery. This study concludes that the volitional strategy through metacognitive development is proved effective in increasing students' motivation for reading, students with both low and high reading skills. This has implications for the efforts to foster motivation for reading by intensively using the strategy for Madrasah Tsanawiyah education contexts.
\end{abstract}

Keywords: Madrasah Tsanawiyah; metacognitive; motivating for reading; self-monitoring; volitional strategy

Reading is an important skill to develop a more literate society. The importance of reading skills for learners has become the focal concern of theorists (Kieffer \& Vukovic, 2013; Olson, Keenan, Byrne \& Samuelsson, 2014; Tighe \& Schatschneider, 2016; van Staden \& Bosker, 2014). Reading is deemed a vitally important skill students should have to attain high achievements in school (Luckner \& Michele, 2008), a fundamental skill for understanding across disciplines (Lei, Rhinehart, Howard \& Cho, 2010), and as a means for achieving a good life skill (Saunders, 2007; Inderjit, 2014; McGeown, Norgate, \& Warhurst, 2012; Ahmadi, Ismail \& Abdullah, 2013).

Reading skill is vital for students so that the progress of a nation can be achieved. This skill is a key to the development of human resource that all countries need to be able to compete globally. However, most Indonesian people still assume that without reading they can still achieve their dreams (Rusyana, 1984). In terms of literacy level, although Indonesia does not really lag behind, most Indonesian people still have low reading interests and need to maintain and expand their reading skills (Lowenberg, 2000).

Many factors affect the process of reading such as readers, reading materials, reading skills, and motivation for reading. Of the various factors, motivation plays a very important role on the success of reading. Melekoglu and Wilkerson (2013) argue that the motivation to read is a crucial factor in reading activities and in improving reading skills. This aspect influences other aspects of successful reading.

Reading motivation or a strong will to achieve success in reading is the decisive factor in the success of reading. Morgan and Fuchs' (2007) study shows that there is a very close correlation between motivation and the ability to read. It is also stated that as the motivation to read increases the students' reading skill will increase as well (Gottfried, 1985; Kwon \& Linderholm, 2014; McGeown, Osborne, Warhurst, Norgate \& Duncan, 2016; Gilakjani \& Sabouri, 2016).

Students who have the motivation to read will read intensively. Good readers read 200 times more than poor readers do, which shows that one of the main variables for the students to read is the motivation to read (Quirk, Schwanenflugel \& Webb, 2009). In other words, for the reading skills to rise, highly intensity reading is called for (Leppanen, Aunola, \& Nurmi, 2005). To obtain high intensity or longer time for the students to read, reading motivation is a necessity (Schiefele, Schaffner, Moller, \& Wigfield, 2012).

Appropriate measures are imperative to increase the motivation to read so that reading intensity continues to increase as well. One such measure is through learning strategies that can maintain student motivation to read. As Keller (2010) remarks increased motivation to learn is crucial to keep so that intensive learning emerges. To foster motivation, certain strategies involving self-control are necessary. 
Among the numerous learning strategies, a volitional strategy is one that can sustain increased motivation. Volitions act as a factor of selfregulation to preserve, promote, and direct oneself to an activity to achieve the goal (Kuhl in Keller, 2010). Volitional control is exercised through students' activities to control their own desires and impulses during learning. This framework explains that the process to control willingness enables a person to take a desired action when interference or other alternative actions present themselves. The opportunities students get to monitor themselves allow them to assess the performance with a sense of comfort. This can lead to changes in motivation (Guthtrie et al., 1998). Further, Corno (2001) states that volitional self-regulation affects follow-through as students attempt to complete academic tasks (McCann \& Turner, 2004).

Furthermore, learning activities adopting a volitional strategy require the development of selfcontrol awareness, i.e. through metacognitive, which is reflective awareness of learning tasks through sensing, assessing and determining the learning task (Efklides, 2008; Kromm, Färber \& Holodynski, 2015; Wathen, 2010). Simply put, Lai (2011) defines metacognitive as thinking about thinking. In Martinez's (2006) term, metacognition is to monitor and control one's thoughts.

In learning to read, Jennings, Caldwell, and Lerner (2006) state that metacognition is an essential awareness to monitor one's reading comprehension. Metacognitive awareness constitutes the reader's awareness, monitoring, and a variety of strategies when reading (Anderson in Yuksel \& Yuksel, 2012). In a similar vein, Gonzales (2013), states "... students need to use different strategies to plan, monitor, and evaluate their learning activities (meta-cognitive strategies), as well as to control their motivation and emotion (volitional strategies). Furthermore, readers' metacognitive ability is positively associated with success in reading comprehension (Mokhtari \& Reichard in Yuksel \& Yuksel, 2012). Similarly, Şen's (2009) study reveals that there is a relationship between metacognitive and reading comprehension.

In practice, the teaching of reading aimed at increasing motivation to read by means of the metacognitive volitional strategy is realized through techniques of comprehending passages. Comprehension is taught through grapho-phonemic decoding, vocabulary development, grammar, comprehension, and discourse comprehension. The teaching of reading requires understanding of speech sounds (Ecalle, Magnan, \& Gibert, 2006, Leicester \& Twelvetrees, 2010) and vocabulary learning (Abraham, 2017; Kang, 2015). In addition, Jennings, et al. (2006) state that to read effectively, one must understand grammar and vocabulary.

Self-control awareness of reading skills is strengthened by self-monitoring questions (Eme, Puustinen, \& Coutelet, 2006). This strategy aligns with Broussard \& Garrison's (2004) finding that recent research on motivation tends to collect data through questions that are grouped on three following questions.

1. Can I complete the task?

2. Do I want to complete this task and why?

3. What should I do to fruitfully complete the task?

The objective of implementing this type of learning strategy was to increase the motivation to read through volitional control of reading comprehension skills. Through metacognitive strengthening, awareness of enhancing the willingness to read, accepting the task of reading and reading comprehension ability can be sustained. Learning materials were delivered through understanding the passages. Based on the aforementioned description, this study sought to prove that the adopted strategy can amplify the students' motivation to read for the students with high or low reading skills.

\section{RESEARCH METHOD}

\section{Research design}

This study used an experimental method, for it aimed to examine the effectiveness of the volitional strategy through metacognitive development in increasing students' reading motivation, for students with low and high reading skills. The study employed a factorial design developed by Fraenkel, Wallen and Hyun (2012). With this design, a moderator variable, i.e. differences in reading skills, as shown in Table 1 below can be controlled.

\section{Treatment procedure}

The treatment was given to both groups of students with high and low reading skills. Both were given as many as nine stages of treatment. The mean time spent in each stage is four sessions over two weeks. The entire process of treatment lasted for six months. The procedure of the treatment is shown in Table 2.

Table 1. Research framework with a factorial design

\begin{tabular}{ccccc}
\hline Pre-test & Treatment & \multicolumn{2}{c}{ Moderator Variable } & Post-test \\
\cline { 3 - 4 } & & $\mathrm{X}$ & Y1 & \\
\hline O1 & & Y1 & O2 \\
\hline O3 & $\mathrm{X}$ & & Y2 & O4 \\
\hline O5 & & & Y2 & O6 \\
\hline O7 & & & O8 \\
\hline
\end{tabular}


Notes:

O1: pre-test to students with high reading skills before the treatment

O2: post-test to students with high reading skills after the treatment

O3: pre-test to students with high reading skills that did not receive the treatment

O4: post-test to students with high reading skills that did not receive the treatment

O5: pre-test to students with low reading skills before receiving the treatment

O6: post-test to students with low reading skills after receiving the treatment

O7: pre-test to students with low reading skills who did not receive the treatment

O8: post-test to students with low reading skills who did not receive the treatment

XY1: The treatment of the volitional strategy through metacognitive development for the experiment group with high reading skills

XY2: The treatment of the volitional strategy through metacognitive development for the experiment group with low reading skills

Table 2. The procedure of treatment

\begin{tabular}{|c|c|c|c|c|}
\hline \multicolumn{5}{|c|}{ The volitional strategy through metacognitive development } \\
\hline Stage & Material & Treatment & Self-monitoring & $\begin{array}{l}\text { No. of } \\
\text { session }\end{array}$ \\
\hline I & $\begin{array}{l}\text { Discussions of } \\
\text { reading } \\
\text { activities }\end{array}$ & $\begin{array}{l}\text { 1. Presentation of books to be } \\
\text { picked and read by the } \\
\text { students } \\
\text { 2. Discussions of reading } \\
\text { activities }\end{array}$ & $\begin{array}{l}\text { 1. What is the reading material today? } \\
\text { 2. How do I feel after following the } \\
\text { lesson today? } \\
\text { 3. Will I be able to understand the } \\
\text { reading lesson today? }\end{array}$ & 2 \\
\hline II & $\begin{array}{l}\text { Teaching } \\
\text { reading } \\
\text { through } \\
\text { decoding I } \\
\text { (sounds) } \\
\end{array}$ & $\begin{array}{l}\text { 3. Finding and pronouncing } \\
\text { new sounds in the words in } \\
\text { the reading } \\
\text { 4. Pronouncing new sounds in } \\
\text { pairs or in group }\end{array}$ & $\begin{array}{l}\text { 1. What is the reading material today? } \\
\text { 2. How do I feel after following the } \\
\text { lesson today? } \\
\text { 3. Will I be able to understand the } \\
\text { reading lesson today? }\end{array}$ & 2 \\
\hline III & $\begin{array}{l}\text { Teaching } \\
\text { reading } \\
\text { through } \\
\text { decoding II } \\
\text { (vocabulary) }\end{array}$ & $\begin{array}{l}\text { 5. Role-playing and simulating } \\
\text { difficult vocabulary from } \\
\text { the reading }\end{array}$ & $\begin{array}{l}\text { 1. What is the reading material today? } \\
\text { 2. How do I feel after following the } \\
\text { lesson today? } \\
\text { 3. Will I be able to understand the } \\
\text { reading lesson today? }\end{array}$ & 3 \\
\hline IV & $\begin{array}{l}\text { Reading } \\
\text { through } \\
\text { vocabulary } \\
\text { comprehension } \\
\text { I }\end{array}$ & $\begin{array}{l}\text { 6. } \begin{array}{l}\text { Doing pantomime for } \\
\text { synonyms and antonyms of } \\
\text { new vocabulary from the } \\
\text { reading }\end{array} \\
\text { 7. } \begin{array}{l}\text { Demonstrating new } \\
\text { vocabulary from the reading }\end{array}\end{array}$ & $\begin{array}{l}\text { 1. What can I do to successfully } \\
\text { comprehend the reading? } \\
\text { 2. What do I want to do so that I can } \\
\text { comprehend the reading? }\end{array}$ & 2 \\
\hline $\mathrm{V}$ & $\begin{array}{l}\text { Reading } \\
\text { through } \\
\text { vocabulary } \\
\text { comprehension } \\
\text { II }\end{array}$ & $\begin{array}{l}\text { 8. Doing a comedy of new } \\
\text { vocabulary from the reading } \\
\text { 9. Dramatizing new highly } \\
\text { difficult vocabulary }\end{array}$ & $\begin{array}{l}\text { 1. What can I do to successfully } \\
\text { comprehend the reading? } \\
\text { 2. What do I want to do so that I can } \\
\text { comprehend the reading? }\end{array}$ & $\begin{array}{l}2 \\
3\end{array}$ \\
\hline VI & $\begin{array}{l}\text { Reading } \\
\text { through } \\
\text { grammar } \\
\text { comprehension }\end{array}$ & $\begin{array}{l}\text { 10. Understanding grammar as } \\
\text { complex language variation } \\
\text { through role-playing }\end{array}$ & $\begin{array}{l}\text { 1. What can I do to successfully } \\
\text { comprehend the reading? } \\
\text { 2. What do I want to do so that I can } \\
\text { comprehend the reading? }\end{array}$ & 1 \\
\hline VII & $\begin{array}{l}\text { Reading } \\
\text { through } \\
\text { grammar } \\
\text { comprehension } \\
\text { II }\end{array}$ & $\begin{array}{l}\text { 11. Differentiating sentence } \\
\text { meanings through } \\
\text { groupwork }\end{array}$ & $\begin{array}{l}\text { What can I do to successfully } \\
\text { comprehend the reading? } \\
\text { 2. What do I want to do so that I can } \\
\text { comprehend the reading? }\end{array}$ & 1 \\
\hline VIII & $\begin{array}{l}\text { Reading } \\
\text { through } \\
\text { grammar } \\
\text { comprehension } \\
\text { III }\end{array}$ & $\begin{array}{l}\text { 12. Dramatizing sentences } \\
\text { through conversations about } \\
\text { direct experience with } \\
\text { nature }\end{array}$ & $\begin{array}{l}\text { 1. What can I do to successfully } \\
\text { comprehend the reading? }\end{array}$ & 3 \\
\hline IX & $\begin{array}{l}\text { Reading } \\
\text { through } \\
\text { discourse } \\
\text { comprehension }\end{array}$ & $\begin{array}{l}\text { 13. Comprehending discourse } \\
\text { through interviews }\end{array}$ & $\begin{array}{l}\text { 1. What can I do to successfully } \\
\text { comprehend the reading? } \\
\text { 2. What do I want to do so that I can } \\
\text { comprehend the reading? }\end{array}$ & $\begin{array}{l}2 \\
2\end{array}$ \\
\hline
\end{tabular}

\section{Research Subjects}

The subjects of this research were the students of an Islamic Junior High School [Madrasah Tsanawiyah] in Bandung, Indonesia. This type of school was picked as the subject of the research, for the students of religious schools tend to have low reading 
motivation and therefore should receive more attention (Owodally, 2011).

The number of the students participating in this research were 32 (experiment group) and 37 (control group). Then the former group was divided into two groups, the students with high and low reading skills. Further details of the research subjects are presented in Table 3 below.

Table 3. Research Subjects

\begin{tabular}{lc}
\hline \multicolumn{1}{c}{ Effective reading skills } & $\begin{array}{c}\text { Amount of } \\
\text { students }\end{array}$ \\
\hline Experiment group of high reading skills & 16 \\
\hline Experiment group of low reading skills & 16 \\
\hline Control group of high reading skills & 18 \\
\hline Experiment group of low reading skills & 19 \\
\hline
\end{tabular}

\section{Research Instruments}

The instruments used consist of three types, namely reading motivation inventory instrument, effective reading skill test, and self-monitoring checklist. Cambria \& Guthrie's (2010) parameters of reading motivation inventory instrument were adopted, as follows:

1. Willingness to read to acquire knowledge through reading activities;

2. Willingness to read to get satisfaction through reading activities;

3. Willingness to read to gain the ability to interact socially through reading activities;

4. Willingness to read to overcome difficulties in reading;

5. Willingness to read to improve reading skills through reading activities.

The test used to assess the student's ability to understand the reading is the effective reading ability test using the parameters with reference to Bloom's Taxonomy (Anderson et al., 2001), i.e. remembering, understanding, applying, and analyzing. The questions were in the form of questions that describe students' reading comprehension. The questions comprise questions of finding specific facts, main idea, cause and effect, vocabulary, and grammar. The passages used consisted of four topics under natural sciences and social sciences.
To obtain metacognitive data, self-monitoring checklist was made through a list of questions such as the following.

1. What is the learning material to read today?

2. How do I feel when following reading activities?

3. Will I be able to understand the reading lesson today?

4. What can I do to successfully comprehend the reading?

5. What do I want to do so that I can comprehend the reading?

\section{Hypotheses}

The following are the hypotheses of this study with regard to probing the effectiveness of the volitional strategy through metacognitive development in fostering the students' motivation to read.

1. The volitional strategy through metacognitive development is effective in fostering the motivation to read for the students with high reading skills.

2. The volitional strategy through metacognitive development is effective in fostering the motivation to read for the students with low reading skills.

\section{RESEARCH FINDINGS \\ Reading motivation of the students with high reading skills}

Data of the students' motivation to read is produced through the processing of reading motivation inventory data from both groups of the students, good and poor readers, before and after receiving the treatment using the volitional strategy with metacognitive development. The data in question are presented in Table 4 . Results of the research in Table 4 can be interpreted in several ways. Before receiving the treatment, the students with high reading skills were highly motivated on two aspects: (1) the motivation of reading to improve reading skills and (2) the motivation of reading for social interaction. The mean scores of the two aspects of motivation were 21.90 and 19.09 , respectively. These scores are far higher than the mean of the ideal score of every aspect of reading, i.e. 18.00.

Table 4. Reading motivation of the students with high effective reading skills

\begin{tabular}{lcccc}
\hline \multirow{2}{*}{ Aspect of reading motivation } & \multicolumn{2}{c}{ Mean score } & \multicolumn{2}{c}{$\begin{array}{c}\text { Standard deviation } \\
\text { score }\end{array}$} \\
\hline & Pretest & Posttest & Pretest & Posttest \\
\hline Gaining Knowledge & 17.41 & 14.53 & 3.66 & 2.03 \\
\hline Getting Satisfaction & 14.59 & 12.69 & 2.20 & 2.20 \\
\hline Social Interaction & 19.09 & 20.85 & 3.80 & 3.40 \\
\hline Overcoming Difficulties & 16.87 & 17.22 & 4.05 & 3.64 \\
\hline Ability to Read & 21.90 & 24.72 & 3.74 & 3.00 \\
\hline
\end{tabular}

The data above also demonstrate that before receiving the treatment, the good readers group had low motivation on three kinds of aspects of reading, namely (1) the motivation to gain knowledge from reading, (2) the motivation of reading to get satisfaction from reading, and (3) the motivation of 
reading to overcome difficulties in reading. This interpretation can be seen from the mean scores of the three aspects of motivation, i.e. 17.41, 14.59, and 16.87 , respectively. These scores are far below the mean of the ideal score for each aspect of motivation of reading.

Furthermore, the data in Table 4 show that after receiving the treatment, the students with high reading skills were strongly motivated to improve their reading skills and to interact socially. This is shown by the mean scores of the two aspects of motivation, i.e. 24.72 and 20.85 , respectively. When compared to the ideal score, i.e. 18.00, the scores of the two aspects are higher.

In addition, after the treatment, three aspects of reading motivation were found lower in the experiment group consisting of good readers. They are (1) the motivation to gain knowledge from reading, (2) the motivation of reading to get satisfaction from reading, and (3) the motivation of reading to overcome difficulties in reading. The mean scores are 14.53; 12.69; and 17.22, respectively.

The effectiveness of teaching reading with the volitional strategy to foster motivation of the students with high reading skills

Based on the acquired data, with $\mathrm{t}=3.33$ and $\mathrm{t}$ table criteria at 2.00 , it can be concluded that at $95 \%$ confidence level, meaning that Ho is rejected. In other words, after learning to read with the volitional strategy, the good readers group exhibited motivation higher than before they received the treatment. Simply put, this strategy is effective to foster the motivation of the students with high reading skills.

\section{Reading motivation of the students with low reading skills}

What follows, as presented in Table 5, is the profile of reading motivation of the students with low reading skills.

Table 5. Reading motivation of the students with low reading skills

\begin{tabular}{lcccc}
\hline \multirow{2}{*}{ Aspect of reading motivation } & \multicolumn{2}{c}{ Mean score } & \multicolumn{2}{c}{$\begin{array}{c}\text { Standard deviation } \\
\text { score }\end{array}$} \\
\hline & Pretest & Posttest & Pretest & Posttest \\
\hline Gaining Knowledge & 17.28 & 15.41 & 3.41 & 2.75 \\
\hline Getting Satisfaction & 15.09 & 13.53 & 3.32 & 2.79 \\
\hline Social Interaction & 19.75 & 21.10 & 3.68 & 2.33 \\
\hline Overcoming Difficulties & 17.09 & 17.16 & 3.54 & 3.34 \\
\hline Ability to Read & 20.78 & 22.81 & 3.03 & 2.24 \\
\hline
\end{tabular}

Table 5 shows that before the treatment, the students with low reading skills exhibited high reading motivation scores for the purposes of enhancing the ability to read and to interact socially. The score is higher than the mean score of other aspects of motivations and also higher than the mean of the ideal score, i.e. 18.00. The small coefficient of variance of the two aspects of motivation, i.e. $14.58 \%$ and $18.63 \%$, respectively, indicates the same relative level of motivation.

Low motivation scores of this group before the treatment were observed in (1) the motivation to gain knowledge from reading, (2) the motivation of reading to get satisfaction from reading, and (3) the motivation of reading to overcome difficulties in reading. These scores are below the mean of the ideal score. These scores also demonstrate that the three aspects of motivation are similarly low, with a small coefficient of variance, i.e. $19.73 \%, 22.00 \%$, and $20.71 \%$, respectively.

Furthermore, it can also be seen in Table 5 that the poor readers group, after the treatment, exhibited increased motivation on the aspect of the motivation to improve reading skills and for social interaction. The mean scores of the two aspects are 21.10 and 22.81. The similarity of the mean scores of the two aspects is noticeable from the small coefficient of variance at $11.04 \%$ and $9.82 \%$.
The aspects in which this group exhibited low motivation after the treatment are (1) the motivation to gain knowledge from reading, (2) the motivation of reading to get satisfaction from reading, and (3) the motivation of reading to overcome difficulties in reading. The mean scores of the three aspects of motivation are $15.41,13.53$, and 17.16 , respectively. These scores show similarities in terms of relatively small motivation as evidenced in the low correlation coefficients, i.e. $17.48 \%, 20.62 \%$, and $19.46 \%$.

The effectiveness of teaching reading with the volitional strategy to foster reading motivation of the students with low reading skills

To test hypothesis 2 , based on the $\mathrm{t}=4.72$ and $\mathrm{t}$ table criteria at 2.00 , it can be concluded that Ho is rejected at $95 \%$ confidence level. This demonstrates that the volitional strategy is effective to foster the motivation of the students with low reading skills.

\section{Description of the students self-monitoring during the treatment}

Table 6 below exhibits the mechanism of the volitional strategy and qualitative data in the form of descriptions of affective and motivational changes in reading. The mechanism constitutes the stages of learning based on the material in each stage, treatments, self-monitoring questions, and 
Table 6. Self-monitoring descriptions

\begin{tabular}{|c|c|c|}
\hline \multicolumn{3}{|c|}{ The volitional strategy through metacognitive development } \\
\hline Stages & Self-monitoring & Outcome descriptions \\
\hline $\begin{array}{l}\text { I. (Understanding of reading } \\
\text { activities) }\end{array}$ & $\begin{array}{l}\text { 1. Identification of reading materials } \\
\text { 2. Feeling complementing the } \\
\text { understanding of reading activities } \\
\text { 3. Understanding of texts }\end{array}$ & $\begin{array}{l}\text { as per reading materials taught } \\
\text { feeling anxious ( } 31 \%) \\
\text { inability to understand texts owing to } \\
\text { difficulties }(69 \%)\end{array}$ \\
\hline $\begin{array}{l}\text { II. (Sound decoding } \\
\text { materials) }\end{array}$ & $\begin{array}{l}\text { 1. Identification of sound decoding } \\
\text { materials from reading } \\
\text { comprehension } \\
\text { 2. Feeling complementing reading } \\
\text { comprehension through sound } \\
\text { decoding }\end{array}$ & $\begin{array}{l}\text { feeling ashamed and anxious }(20.77 \%) \\
\text { feeling courageous }(29 \%) \\
\text { inability to understand texts owing to } \\
\text { difficulties }(69 \%) \\
\text { feeling doubtful }(8 \%)\end{array}$ \\
\hline $\begin{array}{l}\text { III. (Vocabulary decoding } \\
\text { materials) }\end{array}$ & $\begin{array}{l}\text { 1. Identification of vocabulary } \\
\text { decoding materials from reading } \\
\text { comprehension } \\
\text { 2. Acts complementing teaching } \\
\text { reading through vocabulary } \\
\text { decoding } \\
\text { 3. Impulse to act to comprehend } \\
\text { reading through sounds and } \\
\text { vocabulary understanding }\end{array}$ & $\begin{array}{l}\text { Doing the reading task on their will } \\
\text { Willingness to find interesting words and } \\
\text { sounds to be dramatized }(44 \%)\end{array}$ \\
\hline IV. (Vocabulary materials I) & $\begin{array}{l}\text { 1. Acts complementing teaching } \\
\text { reading through vocabulary } \\
\text { 2. Impulse to act to comprehend } \\
\text { reading through vocabulary } \\
\text { understanding }\end{array}$ & $\begin{array}{l}\text { Gaining understanding of new } \\
\text { vocabulary from hands-on experiences } \\
\text { and real examples } \\
\text { Willingness to read after finding meaning } \\
\text { expansion }(51 \%)\end{array}$ \\
\hline V. (Vocabulary materials II) & $\begin{array}{l}\text { 1. Acts complementing teaching } \\
\text { reading through vocabulary } \\
\text { 2. Impulse to act to comprehend } \\
\text { reading through new vocabulary }\end{array}$ & $\begin{array}{l}\text { Ability to read due to their competence } \\
\text { The poor readers group wanted to read } \\
\text { texts with new vocabulary }(26 \%)\end{array}$ \\
\hline VI. (Grammar materials) & 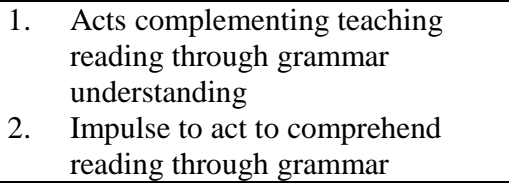 & $\begin{array}{l}\text { Able to read with the awareness of } \\
\text { language variation }(44 \%) \\
\text { Willingness to read to welcome } \\
\text { challenges }\end{array}$ \\
\hline VII. (Grammar materials II) & $\begin{array}{l}\text { 1. } \begin{array}{l}\text { Acts complementing teaching } \\
\text { reading through grammar } \\
\text { understanding }\end{array} \\
\text { 2. } \begin{array}{l}\text { Impulse to act to comprehend } \\
\text { reading through grammar } \\
\text { understanding }\end{array} \\
\end{array}$ & $\begin{array}{l}\text { Ability to read with complex } \\
\text { comprehension }(50 \%) \\
\text { Willingness to read after feeling } \\
\text { challenged to more accurately } \\
\text { comprehend reading }\end{array}$ \\
\hline VIII. (Grammar materials III) & $\begin{array}{l}\text { Impulse to act to comprehend } \\
\text { reading through grammar } \\
\text { understanding }\end{array}$ & $\begin{array}{l}\text { Willingness to comprehend reading } \\
(55 \%)\end{array}$ \\
\hline IX. (Discourse materials) & $\begin{array}{l}\text { 1. } \begin{array}{l}\text { Acts complementing teaching } \\
\text { reading through discourse }\end{array} \\
\text { understanding } \\
\text { 2. } \begin{array}{l}\text { Impulse to act to comprehend } \\
\text { reading through discourse } \\
\text { understanding }\end{array} \\
\end{array}$ & $\begin{array}{l}\text { Willingness to comprehend more } \\
\text { complex yet interesting reading }\end{array}$ \\
\hline
\end{tabular}

Table 6 shows the development of affection and motivation to read after receiving the treatment. Here are the details.

1. Feelings of anxiety, shame, inadequacy, and skeptical of the ability to read from the stage- 1 to stage- 2 was decreasing. This is evident from the percentage of anxiety visible from treatment
1 at $31 \%$, and then it dropped to 20.77 and to $8 \%$ after treatment 3 and 4.

2. In the early stages of learning, the motivation to understand the passage was rather low, $69 \%$ of the students said it was difficult to read. The difficulty level fell to $16 \%$.

3. The motivation to read began to emerge starting treatment 5 . The motivation observed was the 
motivation to read easy materials to difficult materials. It appears from the motivation to find interesting sounds, discover new vocabulary, find the meanings of words, understand language variation, comprehend the discourse, and understand difficult texts.

\section{DISCUSSION}

\section{Students' motivation to read}

The main finding of this study is that the volitional strategy through metacognitive development increases students' reading motivation. Increase of motivation to read after the treatment is highly significant at $95 \%$ confidence level, which took place with both groups of the students, with low and high reading skills. With the poor readers group, the increase is significant at $12.88 \%$ and with the good readers group it is at $9.82 \%$.

The present study confirms that there is an increase in the students' reading motivation with high reading skills after receiving the treatment. This is in accordance with what Schaffner, Philip and Schiefele (2014) found with children with high reading skills. Their research provides evidence that there is a significant relationship between intrinsic motivation and reading among the students who are good readers.

The good readers are the ones who have a high learning orientation. This is in conformity with Thorkildsen and Nichols (1998); according to which the students with high achievement orientation will strive to outperform the others and achieve good assessment in their learning, including in reading. In fact, motivation to read is associated with a desire to excel in reading (Pitcher et al., 2007; De Naeghel, Van Keer, Vansteenkiste \& Rosseel, 2012; McGeown et al., 2016; Meniado, 2016; Schiefele, Stutz, \& Schaffner 2016).

One of the factors that influences people's motivation for high achievement in reading is their self-concept of the ability to read. Many researchers believe that the students who have high motivation to read will have a self-concept of high orientation of reading to improve understanding of what they read. A study by Marsh and Martin (2011) evinces that self-concept on academic achievement affect to one's ability. More specifically, experts reveal that self-concept of reading is strongly associated with reading skills (Marsh \& Carven, 2006; Valentine \& DuBois, 2005; De Naeghel et al., 2012; Retelsdorf, Köller, \& Möller, 2014; Retelsdorf, Schwartz，\& Asbrock, 2015; Viljaranta, Kiuru, Lerkkanen, Silinskas, Poikkeus, \& Nurmi, 2016). In addition, reading motivation is also linked to the desire to improve reading skills. Other experts affirm that reading motivation is correlated with improved reading skills (Ecalle, et al., 2006; McGeown, Duncan, Griffiths, \& Stothard, 2015; Silinskas at al., 2016; Stutz, Schaffner, \& Schiefele, 2016).
This study also demonstrates that children who are good readers turned out to have high motivation to read for other aspects, such as social interaction (Gambrell, 2011; Knoester 2010). Our results lend support to the stages of adolescent development characterized by a strong desire to interact socially with the environment. The respondents of this study were in their teens. At this age they begin to attach great importance to friendship bound together by common interests. In this respect, Casement et al. (2014) remarked that for adolescents, their relationships with parents and peers are a crucial factor. Along the same line, Guthrie et al. (1998) showed that reading motivation for social interaction is very important aspect. Lin, Wong, \& McBride-Chang (2012) also confirmed that motivation relating to one's social attitudes towards peers is very significant to reading activities, such as reading foreign passages.

Through reading, students can maintain their friendships by exchanging information. They will get satisfied when they can communicate the knowledge they acquired from reading. Experts show that teenagers want to do the reading because reading gives the social functions they need (Goodman \& Goodman, 1979; Adkins \& Brendler, 2015; De Naeghel et al., 2012; Ivey \& Broaddus, 2001; Sani, Chik, Nik, \& Raslee, 2011; Strom, Oguinick, \& Singer, 1995).

Analysis of the data of the poor readers group also indicates increased motivation to read after the treatment. McGeown, Norgate, and Warhurst (2012) show that motivation to read is highly influential to the ability to read, whether they are good or poor readers. Their mean score of motivation; however, appears to be lower than that of the good readers group. The same result is also found by Ecalle et al. (2006) in which case children with high motivation in reading would exhibit better reading skills than those with low motivation.

In fact, the low readers group often did not care about incorrect understanding. They did not obtain meaning from reading, after wards their reading motivation declines significantly (Morgan \& Fuchs, 2007). When they lose the understanding of the meaning of what they read, they do not attempt to read over. They also do not want to try to comprehend the reading (Jennings et al., 2006). If teachers do not make appropriate efforts then this group will continue to perform poorly. What follows are in depth discussions of the mechanisms of the volitional strategy proven to foster the students' motivation to improve reading skills based on the volitional and metacognitive concepts.

\section{Increased Motivation for Reading with the Volitional Strategy}

Analysis of the results of reading teaching by means of the volitional strategy indicates that the students' 
affection and motivation to read increased. Learning activities were laden with high level of motivation to read through self-control and awareness of selfregulation. Motivation related to self-control is based on the theory of values and expectations. According to Eccles and Wigfield (2002) one's values and expectations will underlie a one's activities. Values are the reasons that lead to the emergence of actions. This accords with Guay et al. (2010) according to which motivation is associated with why someone performs actions based on selfregulation integrated with the values and needs that are part of their identity.

Through self-regulation, the students can monitor their own activities, evaluate their ability, and reflect upon their actions to achieve the learning outcomes (Lai, 2011). This is in line with the theory of self-regulation which states that individuals can foster their motivation through a number of strategies of self-regulation through monitoring and evaluating the achievement of a goal (Schunk \& Zimmerman, (2007). The ability to understand and realize one self is associated with metacognition. Metacognition, according to Jennings et al. (2006) is a necessary awareness to monitor oneself in reading comprehension.

Self-monitoring of the students in learning to read with the strategy in question was realized by the students answering the questions on the selfmonitoring form. Analysis of the students' answers reveals that upon the treatment, the students' anxiety, doubt, and difficulty diminished. The atmosphere changes empowered the students. Eccles $\&$ Wigfield (2002) explain that self-confidence is an individual belief of his/her ability to manage and decide to solve a problem. With regard to the issue of motivation to read, Guthrie, Coddington, and Wigfield (2009) demonstrate that students who have positive motivation are those who have a strong belief in their ability to do various reading tasks (see also De Naeghel et al., 2012; Guthrie et al., 2006; McGeown, Duncan, Griffiths, \& Stothard, 2015; Sani, Chik, Nik, \& Raslee, 2011; Stutz, Schaffner, $\&$ Schiefele, 2016). They also show that the students with strong confidence have a clearer goal of reading achievement, readiness to face difficulties, willingness to work hard, and willingness to get engaged.

What is more, analysis of the data from the students displays increased motivation to read is consonant with the students' willingness to comprehend the passage through language skills. Marshall (1981) states that language skills are complex mental processes the reader undertakes when interacting significantly with print texts. Excellent readers are the ones with excellent language skills with written materials. The better a person's ability to read gets, the better his/her ability to comprehend the reading is.

\section{CONCLUSIONS}

High reading skills require a high level of motivation. As such, an appropriate strategy for teaching reading is a must to make students highly motivated to read. This research reveals that the reading motivation of the students with low and high reading skills can both increase as a volitional strategy through metacognitive development was adopted in teaching activities. This underscores the importance of utilizing this strategy with regard to self-control and the awareness of intensive and systematic reading skills mastery in Indonesian junior high school contexts.

\section{ACKNOWLEDGEMENTS}

I am grateful to Yus Rusyana for his feedback and advice to the project on which this article is based.

\section{REFERENCES}

Abraham, L. (2017). Computer-mediated glosses in second language reading comprehension and vocabulary learning: A meta-analysis. Computer Assisted Language Learning, 21(3), 199-226. http://doi.org/10.1080/09588220802090246.

Adkins, D., \& Brendler, B. M. (2015). Libraries and reading motivation: A review of the Programme for International Student Assessment reading results. IFLA Journal, 41(2), 129-139. http://doi.org/10.1177/0340035215578868.

Ahmadi, M. R., Ismail, H. N., \& Abdullah, M. K. K. (2013). The importance of metacognitive reading strategy awareness in reading comprehension. English Language Teaching, 6(10), 235-244. http://doi.org/10.5539/elt.v6n10p235.

Anderson, L. W., Krathwohl, D. R., Airasian, P., Cruikshank, K., Mayer, R., Pintrich, P., ... \& Wittrock, M. (2001). A taxonomy for learning, teaching and assessing: A revision of Bloom's taxonomy. New York. Longman Publishing. Artz, AF, \& Armour-Thomas, E.(1992). Development of a cognitivemetacognitive framework for protocol analysis of mathematical problem solving in small groups. Cognition and Instruction, 9(2), 137-175.

Broussard, S. C. \& Garrison, M. E. B. (2004). The relationship between classroom motivation and academic achievement in elementary school-aged children. Family and Consumer Sciences Research Journal,33(2), 106-120

Cambria, J. \& Guthrie, J. T. (2010). Motivating and engaging students in reading. The NERA Journal, 46(1), 16-29

Casement, M. D., Guyer, A. E., Hipwell, A. E., 
McAloon, R. L., Hoffmann, A. M., Keenan, K. E., \& Forbes, E. E. (2014). Girls' challenging social experiences in early adolescence predict neural response to rewards and depressive symptoms. Developmental cognitive neuroscience, 8,18 27.

Corno, L. (2001). Volitional aspects of selfregulated learning. Self-regulated learning and academic achievement: Theoretical perspectives, 2, 191-225.

De Naeghel, J., Van Keer, H., Vansteenkiste, M., \& Rosseel, Y. (2012). The Relation Between Elementary Students' Recreational and Academic Reading Motivation, Reading Frequency, Engagement, and Comprehension: A Self-Determination Theory Perspective. Journal of Educational Psychology, 104(4), 1006-1021. http://doi.org/10.1037/a0027800

Ecalle, J., Magnan, A., Gibert, F. (2006) Class size effects on literacy skills and literacy interest in first grade: A large-scale inevestigation. Journal of School Psychology,44, 191-209.

Eccles, J. S. \& Wigfield, A., (2002). Motivational beliefs, valuies, and goals. Annual Review of Psychology, 53, 109-132.

Efklides, A. (2008). Metacognition: Defining its facets and levels of functioning in relation to self-regulation and co-regulation. European Psychologist, 13(4), 277-287.

Eme, E., Puustinen, M., \& Coutelet, B. (2006). Individual and developmental differences in reading monitoring: When and how do children evaluate their comprehension? European Journal of Psychology of Education, 21(1), 91-115. https://doi.org/10.1007/BF03173571

Fraenkel, J.R., Wallen, N.E., \& Hyun, H.H. (2012). How to design and evaluate research in education. New York: McGraw Hill.

Gambrell, L. B. (2011). Seven rules of engagement: What's most important to know about motivation to read. Reading Teacher, 65(3), 172-178. https://doi.org/10.1002/TRTR.01024

Gilakjani, A. P., \& Sabouri, N. B. (2016). How can students improve their reading comprehension skill? Journal of Studies in Education, 6(2), 229-240. http://doi.org/10.5296/jse.v6i2.9201.

Goodman, K. S., \& Goodman, Y. M. (1979). Learning to read is natural. In L. B. Resnick \& P. A. Weaver (Eds.), Theory and practice of early reading (pp. 137-154). Hillsdale, NJ: Erlbaum.

Gonzales, M.L.G. (2013). Learning goals and strategies in the self-regulation of learning.US-China Education Review, 3(1), 46-50.

Gottfried, A. E. (1985). Academic intrinsic motivation in elementary and junior high school students. Journal of Educational

Psychology,77, 631-634.

Guay, F., Chanal, J., Ratelle, C. F., Marsh, H. W., Larose, S., \& Boivin, M. (2010). Intrinsic, identified, and controlled types of motivation for school subjects in young elementary school children. British Journal of Educational Psychology, 80(4), 711-735.

Guthrie, J.T., Coddington, C.S., \& Wigfield, A. (2009). Profiles of motivation for reading among African American and Caucasian students. Journal of Literacy Research,41, 317-353.

Guthrie, J. T., Meter, P., McCann, A. D., Wigfield, A., Bennett, L., Poundstone, C. C., ... \& Mitchell, A. M. (1996). Growth of literacy engagement: Changes in motivations and strategies during concept-oriented reading instruction. Reading Research Quarterly, 31(3), 306-332.

Guthrie, J. T., Wigfield, A., Humenick, N. M., Perencevich, K. C., Taboada, A., \& Barbosa, P. (2006). Influences of stimulating tasks on reading motivation and comprehension. The Journal of Educational Research, 99(4), 232 246. http://doi.org/10.3200/JOER.99.4.232246

Inderjit, S. (2014). Reading trends and improving reading skills among students in Malaysia. International Journal of Research In Social Sciences, 3(5), 70-81. Retrieved from http://www.ijsk.org/uploads/3/1/1/7/3117743/ $6 \_$reading_skills.pdf.

Ivey, G., \& Broaddus, K. (2001). “Just plain reading" : A survey of what makes students want to read in middle school classrooms. Reading Research Quarterly, 36(4), 350-377. http://doi.org/10.1002/pits.21593

Jennings, J.H. Caldwell, J.S., \& Lerner, J.A (2006). Reading problems: Assessment and teaching strategies. Boston: Pearson.

Kang, E. Y. (2015). Promoting L2 vocabulary learning through narrow reading. RELC Journal, 46(2), 165-179. http://doi.org/10.1177/0033688215586236

Keller, J. M. (2010). Five fundamental requirements for motivation and volition in technologyassisted distributed learning environment. Inter-Acao, Goiania, 35(2), 305-321.

Kieffer, M. J., \& Vukovic, R. K. (2013). Growth in reading-related skills of language minority learners and their classmates: More evidence for early identification and intervention. Reading and Writing, 26(7), 1159-1194. http://doi.org/10.1007/s11145-012-9410-7

Knoester, M. (2010). Independent reading and the "social turn ": How adolescent reading habits and motivation relate to cultivating social relationships. Networks, 12(1), 1-13. Retrieved from 
http://journals.library.wisc.edu/index.php/net works/article/view/332/411

Kromm, H., Färber, M., \& Holodynski, M. (2015). Felt or false smiles? Volitional regulation of emotional expression in 4-, 6-, and 8-year-old children. Child Development, 86(2), 579-597. http://doi.org/10.1111/cdev.12315

Kwon, H., \& Linderholm, T. (2014). Effects of selfperception of reading skill on absolute accuracy of metacomprehension judgements. Current Psychology, 33(1), 73-88. http://doi.org/10.1007/s12144-013-9198-x

Lai, E. R. (2011). Motivation: A literature review. Person Research's Report. http://www.pearsonassessments.com/resaerch

Lei, S. A., Rhinehart, P.J., Howard, H.A., \& Cho, J.K. (2010). Strategies for improving reading comprehension among college students. Reading Improvement, 47(1), 30-42.

Leicester. M. \&Twelvetrees, R. (2010). Adventure stories for reading, learning, and literacy London: Routledge.

Leppanen, U., Aunola, K., \& Nurmi, J. E.(2005). Beginning readers' reading performance and reading habits. Journal of Research in Reading, 28(4), 383-399.

Lin, D., Wong, K., \& McBride-Chang, C. (2012). Reading motivation and reading comprehension in Chinese and English among bilingual students. Reading and Writing, 235(3), 727-737.

Lowenberg, P. ( 2000).Writing and literacy in Indonesia. Study in Linguistic Science, 30 (1), 135-148.

Luckner, J. L. \& Michele, H. C. (2008). A summary of the reading comprehension research undertaken with students who are deaf or hard of hearing. American Annals of the Deaf, 153(1), 6-36.

Martinez, M. E. (2006). What is metacognition? Phi Delta Kappan, 87(9), 696-699.

Marsh, H. W., \& Craven, R. G., (2006). Reciprocal effects of self-concept and performance from multidimensional perspective: Beyond seductive pleasure and unidimensional perspectives. Perspectives on Psychological Science, 1, 133-163.

Marsh, H. W., \& Martin, A. J. (2011). Academic self-concept and academic achievement: Relations and causal ordering. British Journal of Educational Psychology, 81, 59-77.

Marshall, N. (1981). The application of basic research to reading instruction. In D. F Fischer and C. W. Peters, (Eds) Comprehension and the competent reader (pp. 21-34). New York: Praeger Publisher.

McCann, E,J. \& Turner, J.E. (2004). Increasing student learning through volitional control. Florida State University Teachers College Record,106(9), 1695-1714.
McGeown, S.P, Norgate, R., Warhurst, A. (2012).Exploring intrinsic and extrinsic reading motivation among very good and very poor readers. Educational Research, 54(3), 309-322.

McGeown, S. P., Duncan, L. G., Griffiths, Y. M., \& Stothard, S. E. (2015). Exploring the relationship between adolescent's reading skills, reading motivation and reading habits. Reading and Writing, 28(4), 545-569. http://doi.org/10.1007/s11145-014-9537-9.

McGeown, S. P., Norgate, R., \& Warhurst, A. (2012). Exploring intrinsic and extrinsic reading motivation among very good and very poor readers. Educational Research, 54(3), 309-322. http://doi.org/10.1080/00131881.2012.710089

McGeown, S. P., Osborne, C., Warhurst, A., Norgate, R., \& Duncan, L. G. (2016). Understanding children's reading activities: Reading motivation, skill and child characteristics as predictors. Journal of Research in Reading, 39(1), 109-125. http://doi.org/10.1111/1467-9817.12060

Melekoglu, M. A., \& Wilkerson, K .L. (2013). Motivation to read: How does it change for struggling readers with and without disabilities. International Journal of Instruction, 6(1), 77-88.

Meniado, J. C. (2016). Metacognitive reading strategies, motivation, and reading comprehension performance of Saudi EFL students. English Language Teaching, 9(3), 117-129. http://doi.org/10.5539/elt.v9n3p117

Morgan, P. L., \& Fuchs, D. (2007). Is there a bidirectional relationship between children's reading skill and reading motivation? Council for Exceptional Children,73, 165-183

Olson, R. K., Keenan, J. M., Byrne, B., \& Samuelsson, S. (2014). Why do children differ in their development of reading and related skills? Scientific Studies of Reading, 18, 3854. http://doi.org/10.1080/10888438.2013.800521

Owodally, A. M. A. (2011). Multilingual and literacy practices and social identities in Sunni madrassahs in Mauritius: A case study. Reading Research Quarterly, 46(2), 134-155.

Pitcher, S. M., Albright, L. K., DeLaney, C. J., Walker, N. T., Seunarinesingh, K., Mogge, S., ... \& Dunston, P. J. (2007). Assessing adolescents' motivation to read. Journal of Adolescent \& Adult Literacy, 50(5), 378-396.

Quirk, M., Schwanenflugel, P. J., \& Webb, M. Y. (2009). A short-term longitudinal study of the relationship between motivation to read and reading fluency skill in second grade. Journal of Literacy Research, 41(2), 196-227.

Retelsdorf, J., Köller, O., \& Möller, J. (2014). Reading achievement and reading self- 
concept-Testing the reciprocal effects model. Learning and Instruction, 29, 21-30.

Retelsdorf, J., Schwartz, K., \& Asbrock, F. (2015). “ Michael Can' t Read!" Teachers' gender stereotypes and boys' reading self-concept. Journal of Educational Psychology, 107(1), 186-194. http://doi.org/10.1037/a0037107

Rusyana, Y. (1984). Bahasa dan sastra dalam gamitan pendidikan. Bandung: Diponegoro.

Sani, B. B., Chik, M. N. B. W., Nik, Y. B. A., \& Raslee, N. A. B. (2011). The reading motivation and reading strategies used by undergraduates in University Teknologi MARA Dungun, Terengganu. Journal of Language Teaching and Research, 2(1), 3239. http://doi.org/10.4304/jltr.2.1.32-39

Saunders (2007).Word attack skills in individuals with mental retardation. Mental Retardation and Developmental Disabilities, 13, 78-84.

Schunk, D. H. \& Zimmerman, B. J. (2007).Influencing children's self-efficacy and self-regulation of reading and writing through modeling. Reading \& Writing Quarterly, 23(1), 7-25.

Schaffner, E., Philip, M., \&Schiefele, U. (2014).Reciprocal effects between intrinsic reading motivation and reading competence? A cross-lagged panel model for academic track and nonacademic track students. Journal of Research in Reading,39(1), 19-36.

Schiefele, U., Schaffner, E., Moller, J., \& Wigfield, A. (2012). Dimensions of reading motivation and their relation to reading behaviour and competence. Reading Research Quarterly, 47, 427-463.

Schiefele, U., Stutz, F., \& Schaffner, E. (2016). Longitudinal relations between reading motivation and reading comprehension in the early elementary grades. Learning and Individual Differences, 51, 49-58. http://doi.org/10.1016/j.lindif.2016.08.031

Şen, H. Ş. (2009). The relationsip between the use of metacognitive strategies and reading comprehension. Procedia-Social and Behavioral Sciences, 1(1), 2301-2305.

Silinskas, G., Pakarinen, E., Niemi, P., Lerkkanen, M. K., Poikkeus, A. M., \& Nurmi, J. E. (2016). The effectiveness of increased support in reading and its relationship to teachers' affect and children's motivation. Learning and Individual Differences, 45, 53-64. http://doi.org/10.1016/j.lindif.2015.11.025
Strom, K., Oguinick, C. M., \& Singer, M. I. (1995). What do teenagers want? What do teenagers need? Child \& Adolescent Social Work Journal, 12(5), 345-359. http://doi.org/10.1007/BF01876735

Stutz, F., Schaffner, E., \& Schiefele, U. (2016). Relations among reading motivation, reading amount, and reading comprehension in the early elementary grades. Learning and Individual Differences, 45, 101-113. http://doi.org/10.1016/j.lindif.2015.11.022

Thorkildsen, T., \& Nicholls, J. G. (1998). Fifth graders' achievement orientations and beliefs: Individual and classroom differences. Journal of Educational Psychology, 90, 179-202.

Tighe, E. L., \& Schatschneider, C. (2016). Examining the relationships of component reading skills to reading comprehension in struggling adult readers: A meta-analysis. Journal of Learning Disabilities, 49(4), 395409. http://doi.org/10.1177/0022219414555415

Valentine. J. C.\& DuBois, D. L., (2005). Effects of self-beliefs on academic achievement and vice versa: Separating the chicken from the egg. In H. Marsh, R. G. Craven, \& D.M. McInerney (Eds), International advances in self research (Vol. 2, pp. 53-78). Greenwich, CT: Information Age

van Staden, S., \& Bosker, R. (2014). Factors that affect South African reading literacy achievement : Evidence from prePIRLS 2011. South African Journal of Education, 34(3), 110. http://doi.org/10.4314/saje.v34i3

Viljaranta, J., Kiuru, N., Lerkkanen, M.-K., Silinskas, G., Poikkeus, A.-M., \& Nurmi, J.-E. (2016). Patterns of word reading skill, interest and self-concept of ability. Educational Psychology, 37(6), 712-732. http://doi.org/10.1080/01443410.2016.116579 8

Wathen, T. E. (2010). Developing intentional engagement in adolescents: Volitional and metacognitive strategies use in the classroom. Thesis (Ed. D.)--Talbot School of Theology, Biola University, California, The United States of America.

Yuksel, L. \&Yuksel, I. (2012).Metacognitive awareness of academic reading strategies. Procedia-Social and Behavioral Sciences 31, 894-898. 